\title{
Consumer's Perception towards Online Shopping- A Special Reference to Chennai
}

\author{
P. Nagalakshmi
}

\begin{abstract}
Over the last decade the online shopping is getting more popular across the world. The online consumers became online shoppers because of its convenient and time savings. It is very easy for them to buy the products by simply sitting at a home. Online shopping avoid the waiting time in a shop and make a search for a particular products in a shop. This research work is an attempt to explore the factors that may affect the attitude of consumers in Chennai towards online shopping. The results revealed four important factors viz. reason, problem, satisfaction and technology to be deciding factors of online shopping behaviour of consumers in Chennai.
\end{abstract}

Keywords: Online Shopping, E-Shopping, Home Shopping, Virtual Shopping, Consumer Behaviuor

\section{I.INTRODUCTION}

Online shopping is also known as e-tail. It is derived from "electronic retail" or e-shopping. The act of purchasing products or services over the internet using a web browser. Over the last decade the online shopping is getting more popular across the world. The online consumers became online shoppers because of its convenient and time savings. It is very easy for them to buy the products by simply sitting at a home. Online shopping avoid the waiting time in a shop and make a search for a particular products in a shop.

It is easy for the online shoppers to access the products while they are in move and also relaxing in home or office. Consumers prefer to know the information relating to the products displayed in the internet. It is fulfilled by the online traders. The detailed features or characteristics of all the products are displayed in all the websites. It is easy to educate the consumers about the products and also about the company. The number of choice also available in the internet and it makes the comparison between the various websites.

\section{II.RESEARCH PROBLEM}

Recently the users of online have increased very large in number. Among them many of the users are may become potential consumers for the company which are providing their product and services through online. This is because of rapid and fast developments in the information technologies industry. Online shoppers expect more from their company based on their past experience with all other retailers across the world. This increase the competitiveness among the online traders. If the online traders want to withstand in this market, they have to understand and analysis the needs and preferences of the online shoppers. A new medium of marketing is online selling with new demands of the consumers. Every day the needs and desires of the online consumers increases day by day.

Revised Manuscript Received on 14 December 2020.

Ms. P. Nagalakshmi, Assistant Professor, Department of Commerce, Kalasalingam Academy of Research and Education, Madurai (Tamil Nadu), India.
So, it is an important one for the online traders to know and understand the behaviour of the online consumers. There are many factors affect the behaviour of the online shoppers such as their education level, time savings, their convenient to access, maintenance of their privacy, security measures regarding their payment system, internal and external attributes like personal, Culture, psychological and social behaviour Online shoppers also experienced based on their personal perception with other individual.

Online shopping is based on the consumers' own thinking and personal behaviour. So, among these above mentioned factors psychological factor restricting personally the behaviour of the online shoppers. Online shopping has its own character and its development. So, the present study has taken consumer behaviour towards online shopping

\section{REVIEW OF LITERATURE}

Sougata Banerjee and Sarwatpawar (2013) in this study was focus on predicting the consumer purchase intention. They identified the future customer among the various target groups and how it is helpful to assess the market potentiality. This study is based on the partly exploratory and partly descriptive in nature. It is important to assess the real market in order to positioning their products. This lead to increase the purchase intention of the consumers.

Dr.Renuka Sharma et al, (2014), tried to understand the behaviour of the online shoppers in India. The scope of improvement in online shopping websites. In order to boost up the online shopping in India, it is an important one to offer all the information to the marketing professional regarding marketing strategies. It is found that recent years Indian customers are getting addicted in online shopping. They prefer to know the features of online shopping which are following in the rest of the world. The online consumers are very eager to access e-stores frequently. This is due to easy and convenient to access for $24 * 7$.

Patel Vipulkumarbaldevbhai(2015) is studied the relationship between socio-demography factors and online shopping behaviour. The data is collected through questionnaire in Ahmadabad city of Gujarat. From the finding of study would provide some insight to online retailer on the effect of demography profile on online shopping. Finally the result of this study reveals that there is no influence of gender of respondents on online shopping behaviour while age, income, and education of respondents influence online shopping behaviour consumers.

Dr. S. Karthik, S.Muthupandi (2017) in their study analysed college girls online fashion products. The objectives of this study are to know female consumers awareness and various factors influencing purchasing fashion products through online. The questionnaire collected from 70 female respondents. 
The study reveals that amazon and filpkart is the shopping site which is more preferable by young females. These sites are giving more advertisement through media like TV, Newspaper and websites while comparing other retailers. Most of respondents purchase fashion products online due to ease of purchase, clear \& understandable, capability, and fit for their status, quick shopping, coupled with the discount benefits, compare variety of other items.

\section{OBJECTIVES OF THE STUDY}

- To study the impact of demographic factors on online shopping behaviour of consumer's in Chennai.(gender, age, income, occupation, education).

- To examine what technology do you used for online shopping (personal computer, lap top, mobile, tab, Tele call).

- To identify why consumer's buy online ( price, trust, convenience, and delivery mode).

- To examine the problem faced by consumer towards online shopping (privacy, security, money back, lack of personal services, product return, delivery time) .

- To find out the satisfaction level in online shopping (effectiveness of search, ease of use, time pressure, browsing enjoyment).

\section{V.RESEARCH METHODOLOGY}

\section{A. Source of Data}

This study used both the primary and secondary data. The primary data was collected by using questionnaire. The questionnaire framed to know the demographic profile of the respondents like their gender, age, their income level, educational qualification. This also included their preference towards the online product and also about the online websites which are offering the products from various sellers. The secondary data was taken from various sources like research papers, Journals, magazines and websites.

\section{B. Sampling Design}

Samples were collected from consumers of online shopping of Chennai region. A target of 120 samples was collected through questionnaires. The researcher has used convenient sampling to analysis the data.

\section{Framework of Analysis}

In this study, the researcher has used percentage analysis and $\mathrm{Z}$ test to find out different between general profile of the respondents and purchasing behaviour.

\section{RESULT AND DISCUSSION}

The following are analysis and interpretation of the study.

Table 1 Gender Category wise classification

\begin{tabular}{|l|r|r|}
\hline $\begin{array}{l}\text { GENDER } \\
\text { CATEGORY }\end{array}$ & $\begin{array}{l}\text { TOTAL NO. } \\
\text { OF RESPONSE }\end{array}$ & PERCENTAGE \\
\hline MALE & 61 & 50.8 \\
\hline FEMALE & 59 & 49.2 \\
\hline TOTAL & $\mathbf{1 2 0}$ & $\mathbf{1 0 0}$ \\
\hline
\end{tabular}

(Source: Primary Data).
Female $(51 \%)$ are doing more online shopping than Male $(51 \%)$.

Table 2 Age wise classification

\begin{tabular}{|l|r|r|}
\hline AGE & $\begin{array}{l}\text { NO.OF } \\
\text { RESPONSES }\end{array}$ & PERCENTAGE \\
\hline$<20$ & 25 & 20.8 \\
\hline $21-35$ & 62 & 51.6 \\
\hline $36-50$ & 21 & 17.5 \\
\hline$>50$ & 12 & 10 \\
\hline TOTAL & $\mathbf{1 2 0}$ & $\mathbf{1 0 0}$ \\
\hline
\end{tabular}

(Source: Primary Data).

Mainly persons in the age group 21-35 are engaged in online purchase $(51.6 \%)$. This age group is the "Earning age group "including salaried employees and

Table 3 Qualification wise classification

\begin{tabular}{|l|l|l|}
\hline Qualification & $\begin{array}{l}\text { No of } \\
\text { response }\end{array}$ & Percentage \\
\hline Higher secondary & 23 & $19.20 \%$ \\
\hline UG & 47 & $39.20 \%$ \\
\hline PG & 39 & $32.50 \%$ \\
\hline ANY OTHER & 11 & $9.10 \%$ \\
\hline TOTAL & $\mathbf{1 2 0}$ & $\mathbf{1 0 0}$ \\
\hline
\end{tabular}

(Source: Primary Data).

Graduates $(39.2 \%)$ and post graduates $(32.5 \%)$ are the major targets for the online trading, because they are more conversant with technology of internet usage. Put together they contribute $71 \%$ of the business.

Table 4 Occupation wise classification

\begin{tabular}{|l|r|r|}
\hline \multicolumn{1}{|c|}{ Occupation } & No of response & \multicolumn{1}{c|}{ Percentage } \\
\hline Salaried & 54 & $45 \%$ \\
\hline Professionals & 25 & $20 \%$ \\
\hline business & 16 & $13.30 \%$ \\
\hline Other & 25 & $20.80 \%$ \\
\hline Total & 120 & 100 \\
\hline
\end{tabular}

(Source: Primary Data)

Persons with safe monthly income do more online shopping. Their regular income per month gives them enough to do online shopping.

Table 5 Income wise classification

\begin{tabular}{|l|l|r|}
\hline Income & $\begin{array}{l}\text { No of } \\
\text { response }\end{array}$ & Percentage \\
\hline$<10000$ & 26 & $21.60 \%$ \\
\hline $10000-20000$ & 45 & $37.50 \%$ \\
\hline $20000-40000$ & 28 & $23.30 \%$ \\
\hline $40000-60000$ & 17 & $14.20 \%$ \\
\hline $60000-80000$ & 4 & $3.30 \%$ \\
\hline TOTAL & $\mathbf{1 2 0}$ & $\mathbf{1 0 0}$ \\
\hline
\end{tabular}

(Source: Primary Data)

People in the income group Rs10000-Rs 20000(45\%) do more online shopping. These are younger employees just started their carrier and hence ventured into e-shopping. They are followed by customers in the income group Rs20000-Rs40000 (23.3\%). They matured middle age group people. Hence for matured and 
higher salaried people, the craze for online shopping is almost minimized.

Table 6 Source of information

\begin{tabular}{|l|r|r|}
\hline Item & $\begin{array}{l}\text { No of } \\
\text { response }\end{array}$ & percentage \\
\hline Television & 22 & $18.30 \%$ \\
\hline Online sites & 42 & $35 \%$ \\
\hline Friends & 35 & $29.20 \%$ \\
\hline Relatives & 11 & $9.20 \%$ \\
\hline Newspaper & 10 & $8.30 \%$ \\
\hline Total & $\mathbf{1 2 0}$ & $\mathbf{1 0 0}$ \\
\hline
\end{tabular}

\section{Source: Primary Data}

Customers have more access to internet thereby come to know various online sites. They confirm the reliability of sites through their friends.

Table 7 Convenient technology for online shopping

\begin{tabular}{|l|r|r|}
\hline Item & No of response & percentage \\
\hline Mobile & 48 & $40 \%$ \\
\hline Tab & 9 & $7.50 \%$ \\
\hline Laptop & 34 & $28.30 \%$ \\
\hline $\begin{array}{l}\text { Personal } \\
\text { computer }\end{array}$ & 29 & $24.20 \%$ \\
\hline Total & & $\mathbf{1 0 0}$ \\
\hline
\end{tabular}

\section{Source: Primary Data}

This analysis shows that mobile (cell phone) is the easiest and most preferred access point for online shopping as almost all people possess cell phones with internet connection. This also indicates that mobile with internet facility is the most preferred.

Table 8 Frequency of online shopping

\begin{tabular}{|l|r|r|}
\hline Item & No of response & percentage \\
\hline >one month & 31 & $25.80 \%$ \\
\hline Six month & 26 & $30 \%$ \\
\hline Once a year & 21 & $17.50 \%$ \\
\hline frequent & 17 & $14.20 \%$ \\
\hline Often & 15 & 12.5 \\
\hline Total & $\mathbf{1 2 0}$ & $\mathbf{1 0 0}$ \\
\hline
\end{tabular}

\section{(Source: Primary Data)}

People buy goods online mostly every six month. These are people who buy goods during festival season due to large discounts offered during that period. Frequent online shoppers generally buy cosmetics items and groceries

Table 9 Favorites Site choosing for online shopping

\begin{tabular}{|l|r|r|}
\hline \multicolumn{1}{|c|}{ ITEM } & $\begin{array}{l}\text { NO OF } \\
\text { RESPONSE }\end{array}$ & PERCENTAGE \\
\hline FLIPKART & 54 & $45 \%$ \\
\hline AMAZON & 22 & $\mathbf{1 8 . 3 0 \%}$ \\
\hline SNAPDEAL & 25 & $20.80 \%$ \\
\hline PAYTM & 12 & $10 \%$ \\
\hline
\end{tabular}

\begin{tabular}{|l|r|r|} 
ASKME & 7 & $5.90 \%$ \\
\hline TOTAL & 120 & 100 \\
\hline
\end{tabular}

(Source: Primary Data)

Customer mostly prefer flip kart because of ; (i) low price and more discount, (ii) fast delivery, iii) best quality product.

Table 10 Customers' satisfaction level towards online shopping

(No. of Respondents $=120$ )

\begin{tabular}{|c|c|c|c|c|c|c|}
\hline Statements & $\mathbf{S A}$ & $\overline{\mathbf{A}}$ & $\mathbf{N}$ & $\mathbf{D A}$ & SDA & $\begin{array}{l}\text { Mean } \\
\text { Deviation }\end{array}$ \\
\hline $\begin{array}{l}\text { Time } \\
\text { Saving }\end{array}$ & 90 & $\begin{array}{l}1 \\
0\end{array}$ & $\begin{array}{l}1 \\
0\end{array}$ & 5 & 5 & 4.458 \\
\hline $\begin{array}{l}\text { Quality of } \\
\text { product }\end{array}$ & 60 & $\begin{array}{l}2 \\
0\end{array}$ & $\begin{array}{l}2 \\
0\end{array}$ & 10 & 10 & 3.916 \\
\hline $\begin{array}{l}\text { No Security } \\
\text { Problem }\end{array}$ & 10 & $\begin{array}{l}1 \\
0 \\
\end{array}$ & $\begin{array}{l}1 \\
0 \\
\end{array}$ & 20 & 70 & 1.916 \\
\hline $\begin{array}{l}\text { Right } \\
\text { product in } \\
\text { right Time }\end{array}$ & 5 & 5 & $\begin{array}{l}1 \\
0\end{array}$ & 40 & 60 & 1.791 \\
\hline Convenient & 80 & $\begin{array}{l}3 \\
0\end{array}$ & 6 & 2 & 2 & 4.53 \\
\hline $\begin{array}{l}\text { It helps to } \\
\text { access } \\
\text { recent } \\
\text { products }\end{array}$ & 60 & $\begin{array}{l}2 \\
0\end{array}$ & $\begin{array}{l}2 \\
0\end{array}$ & 10 & 10 & 3.916 \\
\hline $\begin{array}{l}\text { Information } \\
\text { about the } \\
\text { product is } \\
\text { good }\end{array}$ & 5 & 5 & $\begin{array}{l}1 \\
5\end{array}$ & 20 & 75 & 1.708 \\
\hline
\end{tabular}

(Source: Primary Data)

\section{FINDINGS AND SUGESTION}

Yes, it saves more time follow than the traditional method; it gives better price, more variety, easy price comparisons, no crowds, no pressures in the online shop. Customers don't have to spend time travelling or parking your car at busy car Parks. Shopping online easy and with delivery to your doors and very comfortable. Online stores provide home delivery service for free or small fee spend in the shop. There is always risk of security of payment through cash cards, and it's difficult to unknown seller. It is very easy to cancel the transaction, customer to know the detail about the door delivery seller. Availability of online shop, non-stop access, online shopping is allows you to shop anytime from any vendor anywhere in the world. Across multiple market place. But at the same time desire product availability is less at the time of the shop. An easy and convenient shopping including home delivery. It has become recently a very popular and comfortable way of shopping, save money, health and energy. Customers don't have to stand in queues. Customers don't have to carry shopping products. A lot of new trendy products are emerging with a propounding influence. E-commerce giant like Amazon, Wal-Mart, Alibaba have been at the forefront of adopting and benefiting from such trends.Access denied to our favorite brand, product display clarity is low, untested product. So product must display clearly. To make the product test after delivery to the doorstep.

\section{CONCLUSION}


There are many other research scholars and academicians have undergone their study which are relating to online shopping like factors affecting the buying behaviour of consumers and so on across the world.

This study attempted to know the consumer's perception towards online shopping particularly in Chennai. There are 120 sample were drawn from the population by following convenient sampling. The statistical tools like t-test and mean deviation were used to attain the findings for the said objective. The results revealed four important factors viz. reason, problem, satisfaction and technology are most affecting factors of online shopping behaviour of consumers in Chennai. According this research it's provides a model of key factors affecting online consumer behaviour. This research can be extended in many ways. We could include more categories of factors and more attributes such as social influences factors(urban, rural, etc...).

\section{REFERENCES}

1. Sanjeevkumar\&SavitaMaan (2014), "status \& scope of online shopping : An interview analysis through literature review", international journal of advance research in computer science and management studies, vol.2, issue 12, ISSN: 2321-7782. WWW.ijarcsms.com.

2. Shaileshpandey et al..(2014), "consumer behaviour towards retails outlets India", international journal of engineering and management research, vol.4, issue-2, ISSN NO: 2250-0758, Pp; 228-231. www.ijemr.net

3. Kisanshivajirao Desai (2014), "consumer buying behaviour of cosmetic products in Kolhapur", vol.1, issue-10, ISSN: 2347-2723.

4. DahiyaRicha (2012), "Impact of demography factors of consumers on online shopping behaviour in India", journal of international journal of engineering and management sciences, vol.3 (1), ) (ISSN 2229-600x), Pp: 43-52.

5. SajjadNazir et al(2012), "Hoe online shopping is affecting consumers buying behaviour in Pakistan? ", IJCSI international journal of computer sciences issues, vol.9, issue.3. NO 1,(ISSN: 1694-0814). WWW.IJCSI.org

6. Dr.S.Karthik and S.Muthupandi (2017), "A study on Consumer Behaviour towards online Fashion Products in Virudhunagar CityCollege Girls", World Wide Journal of Multidisciplinary Research and Development, 3(12), 233-236.

\section{AUTHORS PROFILE}

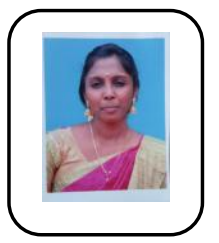

Ms. P.Nagalakshmi.M.com. M. phil.

Assistant Professor, Department of Commerce.

Kalasalingam Academy of Research and Education. She has published 3 papers in the listed journal. 